\title{
The effects of growing density and fertilization on morphological seedling characteristics of crimean juniper (Juniperus excelsa Bieb.)
}

\author{
Yunus Eser," (i), Süleyman Gülcü̈ ${ }^{\mathrm{b}}$ (i)
}

\begin{abstract}
In this study, the effects of growing density and fertilization on the morphological characteristics of the Crimean Juniper (Juniperus excelsa Bieb.) seedlings were investigated. For this purpose, four different growing densities [150, 250, 350 and 600 (= control) seedlings per square meter $]$ and three different fertilizer doses $[0 \mathrm{~g} \mathrm{~N}$ (= control), $10 \mathrm{~g} \mathrm{~N}$ and $20 \mathrm{~g} \mathrm{~N}$ per square meter] were studied. In this context, the effects of the treatments on the height $(\mathrm{SH})$, root collar diameter $(\mathrm{RCD})$, number of sub branches (NSB), the longest lateral root length (LRL) and shoot:root ratio (S:R) of the seedlings, which are among the important morphological characteristics, were examined. The data were evaluated in SPSS software. Results showed that the main factor affecting the root collar diameter of the seedlings was growing density. Similarly, it was found that the main factor working on the seedling height was fertilization dose. As a conclusion; it was suggested that cultivation of barerooted Crimean Juniper seedlings in the Eğirdir Forestry Nursery should be carried out with $150-350$ seedlings per square meter and $10 \mathrm{~g} / \mathrm{m}^{2} \mathrm{~N}$ application.
\end{abstract}

Keywords: Growing density, Fertilization, Crimean Juniper (Juniperus excelsa Bieb.), Seedling quality

\section{Boylu Ardıç (Juniperus excelsa Bieb.)' ta yetiştirme sıklığı ve gübrelemenin fidan morfolojik özellikleri üzerine etkileri}

\begin{abstract}
Özet: Bu çalışmada, yetiştirme sıklığı ve gübrelemenin boylu ardıç (Juniperus excelsa Bieb.) fidanlarının morfolojik özellikleri üzerine etkileri araştırılmıştır. Bu amaçla, dört farklı sıklık derecesi [metrekarede 150, 250, 350 ve 600 (=kontrol) fidan] ve üç farklı gübre dozu [metrekareye $0 \mathrm{~g} \mathrm{~N}$ (=kontrol), $10 \mathrm{~g} \mathrm{~N}$ ve $20 \mathrm{~g} \mathrm{~N}$ ] denemeye alınmıştır. Bu bağlamda, uygulanan işlemlerin önemli fidan morfolojik özelliklerinden olan fidan boyu, kök boğazı çapı, yan dal sayısı, en uzun yan kök boyu ve gövde/kök kuru ağılık oranı üzerine olan etkileri incelenmiştir. Denemeye alınan işlemler sonucunda elde edilen veriler SPSS paket programında değerlendirilmiştir. Buna göre; fidanların kök boğazı çapı üzerine etkili olan temel faktörün yetiştirme sıklığı olduğu ortaya çıkmıştır. Aynı şekilde, fidan boyu üzerine etkili olan temel faktörün ise gübreleme dozu olduğu tespit edilmiştir. Sonuç olarak; Eğirdir Orman Fidanlığında yürütülen boylu ardıç fidanı yetiştirme çalışmalarının, metrekarede 150-350 fidan olacak şekilde yapılması ve metrekareye $10 \mathrm{~g} \mathrm{~N}$ verilmesi uygun olacaktır.

Anahtar kelimeler: Yetiştirme sıklığı, Gübreleme, Boylu ardıç (Juniperus excelsa Bieb.), Fidan kalitesi
\end{abstract}

\section{Introduction}

$92 \%$ of the juniper forests covering 1.1 million hectares in Turkey, are in a condition which cannot provide the benefits expected both qualitatively and quantitatively (Gültekin et al., 2003). Furthermore, in these unfavorable forest lands, the soil has lost its biologic activity and it is under the danger of erosion, as well. As junipers can grow in extreme site conditions and are usually the last tree species remaining in the deforestation process, they are the most suitable ones for the mentioned degraded lands to be afforested. In addition, the use of high quality seedling is one of the most important factors effecting the success of the afforestation in unfavourable sites (Ürgenç, 1986; Negiz et al., 2015).

Since they are practicable and easy to be used, seedling morphological characters are used much more than physiological characters in quality classification (Larsen et al., 1986; Long and Carrier, 1993; Jelin et al., 2013).
Some such factors as fertilization, irrigation, shading, seedling age, root cutting and transplantation effect the morphological characters. Another important factor is seedling density and it is thus crucial to determine the cultivation density of the species. It is known that growing density in seedbeds effects the seedling height, root collar diameter and dry weight positively and those seedlings which were cultivated on the seedbed thinly are more successful in the field than the ones which were cultivated densely (Gezer, 1986; Tetik, 1995; Jacobs et al., 2005).

In addition to seedbed density, fertilization also plays a crucial role in the change of morphological features. A significant part of the nutrients taken by the plants are stored in fresh shoots, sprouts and leaves, and they are used actively in times of need (blooming, root development etc.) (Puttonen, 1997; Trubat et al., 2010). Therefore, fertilization positively effects the post-planting development of the seedlings. For example, it increases their cold and drought

\footnotetext{
\ a Isparta Uygulamalı Bilimler Üniversitesi, Sütçüler Prof.Dr. Hasan Gürbüz Meslek Yüksekokulu, Isparta

b Isparta Uygulamalı Bilimler Üniversitesi, Orman Fakültesi, Isparta

@ * Corresponding author (İletişim yazarı): yunuseser@isparta.edu.tr

$\checkmark \quad$ Received (Geliş tarihi): 15.11.2018, Accepted (Kabul tarihi): 21.03.2019
}

Citation (Atıf): Eser, Y., Gülcü, S., 2018. The effects of growing density and fertilization on morphological seedling characteristics of crimean juniper (Juniperus excelsa Bieb.). Turkish Journal of Forestry, 20(1): 15-19. DOI: $10.18182 /$ tjf. 483157 
tolerances (Fisher and Mexal, 1984; Sharma and Singh, 2011).

The main aim of the study is to identify the effects of growing density and fertilization on some morphological seedling quality attributes for Crimean Juniper (Juniperus excelsa Bieb.).

\section{Material and methods}

Bare root Crimean Juniper seedlings $(1+0)$ originating from the seeds, which were collected in Isparta/Çamdağ locality and grown in Eğirdir Forest Nursery under open field conditions, were used in this study. Four different growing densities and three different fertilizer dosages, in total 12 combinations, were applied with three replications in completely randomized design. As a control, a growing density of 600 seedlings per square meter were used. These seedlings were thinned to various density levels $(150,250$, 350 seedlings per square meter) at the end of May. During the thinning process, we ensured that the remaining seedlings were distributed homogeneously (Çiçek et al., 2010; Gond et al., 2013).

As the total nitrogen concentration was low $(0.1 \%)$ and $\mathrm{pH}$ was high (7.8) in the soil analyses which were performed in the studied nursery, ammonium sulphate $\left[\left(\mathrm{NH}_{4}\right)_{2} \mathrm{SO}_{4}\right]$ fertilizer containing $21 \%$ nitrogen, was used in the fertilization test. The fertilizer, diluted in equal amounts of water, was applied to the seedbeds at the end of June and irrigation was performed following the fertilization. In the fertilization test, two different dosages (10 and $20 \mathrm{~g} \mathrm{~N}$ per square meter) were applied in addition to the control $(0 \mathrm{~g} \mathrm{~N}$ per square meter). Measurements were performed on a sample of 30 seedlings in each repetition for every treatment, in total 1080 seedlings, at the end of October. Morphological attributes such as the seedling height $(\mathrm{cm})$, root collar diameter (mm), number of sub branches (pieces), the longest lateral root length $(\mathrm{cm})$ and shoot: root ratio $(\mathrm{g})$ of the seedlings were all measured.

The obtained data was analysed by the SPSS 10.0 software. We examined whether the data for the measured parameters show normal distribution before the analyses, and the outliers were removed accordingly (Kalıpsız, 1981; Yildiz and Bircan, 1991; 1994). Furthermore, square root transformation was applied for the number of sub branches, which were obtained by counting. The statistical model used in the variance analyses (ANOVA) performed for the data evaluation is given below.

$Y_{i j k m}=\mu+R_{i}+D_{j}+F_{k}+R_{i} D_{j}+R_{i} F_{k}+D_{j} F_{k}+R_{i} D_{j} F_{k}+e_{m(j i k)}$

Where $\mathrm{Y}_{\mathrm{ijkm}}$ is the measurement on the $\mathrm{m}^{\text {th }}$ seedling of the $\mathrm{k}^{\text {th }}$ dose of fertilizer from the $\mathrm{j}^{\text {th }}$ seedling density in the $\mathrm{i}^{\text {th }}$ replication; $m$ is the overall mean; $R_{i}$ is the effect of $i^{\text {th }}$ replication $(i=1,2,3) ; D_{j}$ is the effect of $j^{\text {th }}$ seedling density $\left(j=150,250,350\right.$ and Control); $F_{k}$ is the effect of $k^{\text {th }}$ fertilizer dose $(0,10,20) ; R_{i} D_{j}$ is the interaction effect between $i^{\text {th }}$ replication and $j^{\text {th }}$ seedling density; $R_{i} F_{k}$ is the interaction between $i^{\text {th }}$ replication and $\mathrm{k}^{\text {th }}$ fertilizer dose; $\mathrm{D}_{\mathrm{j}} \mathrm{F}_{\mathrm{k}}$ is the interaction between $\mathrm{j}^{\text {th }}$ seedling density $\mathrm{k}^{\text {th }}$ fertilizer dose; $\mathrm{R}_{\mathrm{i}} \mathrm{D}_{\mathrm{j}} \mathrm{F}_{\mathrm{k}}$ is the interaction between $i^{\text {th }}$ replication, and $\mathrm{j}^{\text {th }}$ seedling density and $\mathrm{k}^{\text {th }}$ fertilizer dose and em(ijk) are the residuals.

\section{Results}

According to the results of the variance analysis, the fertilizer dosage significantly acted on seedling height and number of sub branches. The growing density increased root collar diameter and shoot: root ratio considerably. The main effects of the treatments did not have any effects on the longest lateral root height while their combined effects were statistically significant. The observed differences of shoot:root ratio is dramatically worked on by the growing density and fertilizer dosage and their interaction (Table 1; Figure 1).

A height of $18.5 \mathrm{~cm}$ for the highest average seedling was measured for the application of $20 \mathrm{~g} \mathrm{~N}$ per square meter, while a height of $15.9 \mathrm{~cm}$ for the lowest average seedling was measured in the control (Table 2). In addition, as growing density increases, the need for fertilizer also goes up (Figure 1). The highest average root collar diameter of $2.8 \mathrm{~mm}$ was obtained in the application represented by 150 seedlings per square meter while the lowest average diameter of $2.1 \mathrm{~mm}$ was measured in the application represented by 600 seedlings per square meter (Table 2).

Table 1. Results of variance analysis of the important morphological characteristics

\begin{tabular}{|c|c|c|c|c|c|c|}
\hline Source of variation & $\begin{array}{c}\text { Degrees of } \\
\text { freedom }\end{array}$ & $\begin{array}{l}\text { Seedling } \\
\text { height } \\
(\mathrm{cm})\end{array}$ & $\begin{array}{l}\text { Root collar } \\
\text { diameter } \\
(\mathrm{mm})\end{array}$ & $\begin{array}{l}\text { Number of } \\
\text { sub branches } \\
\text { (pieces) }\end{array}$ & $\begin{array}{l}\text { The longest } \\
\text { lateral root } \\
\text { length }(\mathrm{cm})\end{array}$ & $\begin{array}{l}\text { Shoot:root } \\
\text { ratio } \\
(\mathrm{g})\end{array}$ \\
\hline Seedling density & 3 & $0.845 \mathrm{~ns}$ & $0.000 * * *$ & $0.052 \mathrm{~ns}$ & $0.096 \mathrm{~ns}$ & $0.003 * *$ \\
\hline Fertilizer dose & 2 & $0.006^{* *}$ & $0.255 \mathrm{~ns}$ & $0.032 *$ & $0.131 \mathrm{~ns}$ & $0.266 \mathrm{~ns}$ \\
\hline Replication & 2 & $0.815 \mathrm{~ns}$ & $0.453 \mathrm{~ns}$ & $0.806 \mathrm{~ns}$ & $0.248 \mathrm{~ns}$ & $0.822 \mathrm{~ns}$ \\
\hline Seedling density $\mathrm{x}$ Fertilizer dose & 6 & $0.509 \mathrm{~ns}$ & $0.228 \mathrm{~ns}$ & $0.364 \mathrm{~ns}$ & $0.125 \mathrm{~ns}$ & $0.313 \mathrm{~ns}$ \\
\hline Seedling density x Replication & 6 & $0.650 \mathrm{~ns}$ & $0.345 \mathrm{~ns}$ & $0.227 \mathrm{~ns}$ & $0.189 \mathrm{~ns}$ & $0.741 \mathrm{~ns}$ \\
\hline Fertilizer dose $\mathrm{x}$ Replication & 4 & $0.740 \mathrm{~ns}$ & $0.545 \mathrm{~ns}$ & $0.803 \mathrm{~ns}$ & $0.274 \mathrm{~ns}$ & $0.005^{* *}$ \\
\hline Seedling density $\mathrm{x}$ Replication $\mathrm{x}$ Fertilizer dose & 12 & $0.000 * * *$ & $0.001 * * *$ & $0.000 * * *$ & $0.027 *$ & $0.000 * * *$ \\
\hline The residuals & 983 & & & & & \\
\hline
\end{tabular}

*: Significant at $\mathrm{P}<0.05 ; * *$ : significant at $\mathrm{P}<0.01 ; * * *$ : significant at $\mathrm{P}<0.001 ;$ ns: insignificant 

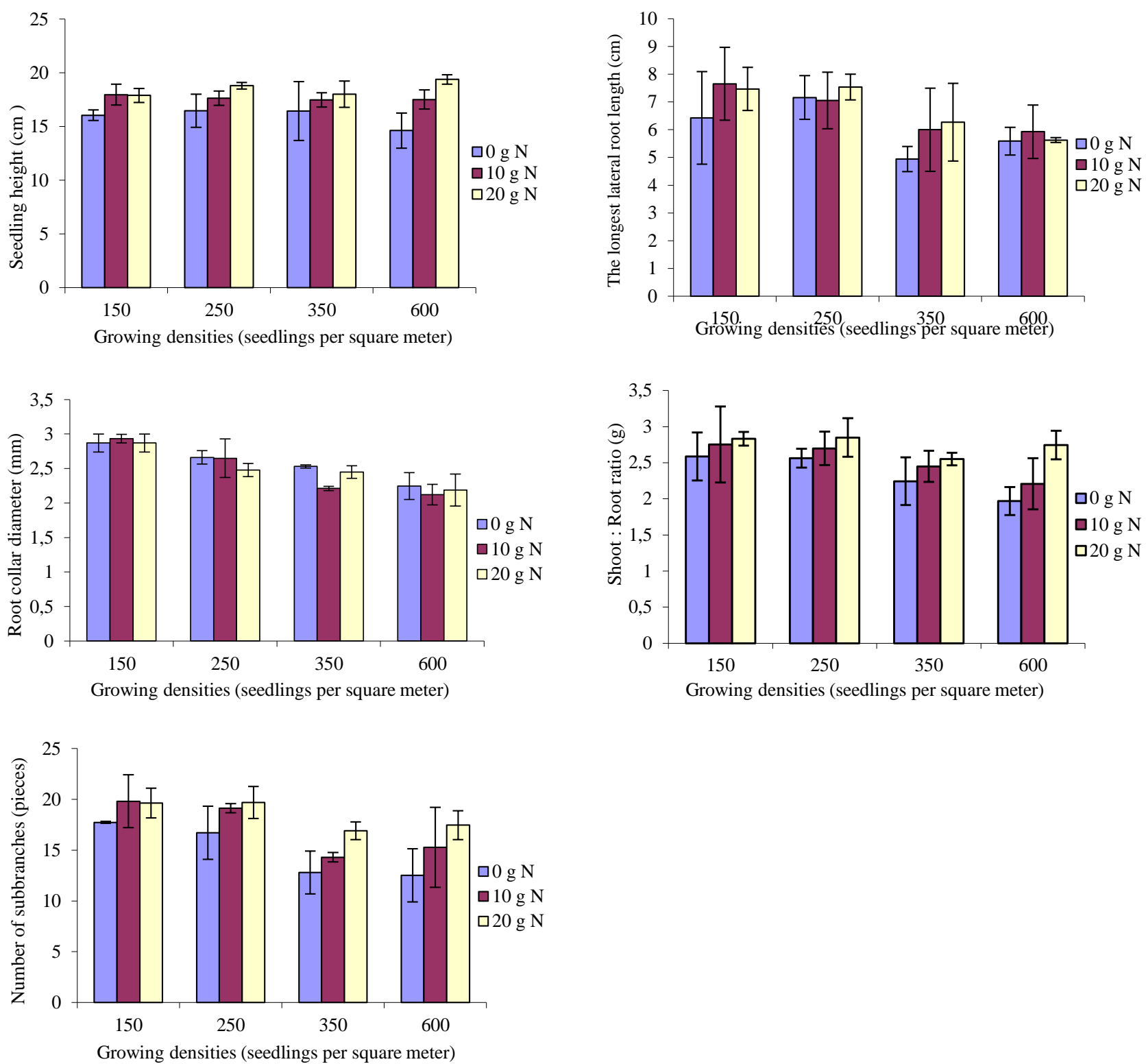

Figure 1. Average values and standart deviations of seedlings morphological attributes at different growing densities and fertilizer doses

Table 2. Results of duncan test of the important $\underline{\text { morphological characteristics }}$

\begin{tabular}{|c|c|c|c|c|}
\hline $\begin{array}{l}\text { Doses of } \\
\text { Fertilizer } \\
\quad(\mathrm{g})\end{array}$ & $\begin{array}{c}\text { Average } \\
\text { seedling } \\
\text { height } \\
(\mathrm{cm})\end{array}$ & $\begin{array}{l}\text { Average } \\
\text { root collar } \\
\text { diameter } \\
(\mathrm{mm})\end{array}$ & $\begin{array}{c}\text { Average } \\
\text { number of } \\
\text { sub } \\
\text { branches } \\
\text { (pieces) }\end{array}$ & $\begin{array}{l}\text { Average } \\
\text { shoot:root } \\
\text { ratio } \\
\text { (g) }\end{array}$ \\
\hline 0 & $15.9^{\mathrm{c}}$ & $2.6 \mathrm{~ns}$ & $16^{\mathrm{c}}$ & $2.3 \mathrm{~ns}$ \\
\hline 10 & $17.6^{\mathrm{b}}$ & $2.5 \mathrm{~ns}$ & $17^{\mathrm{b}}$ & $2.5 \mathrm{~ns}$ \\
\hline 20 & $18.5^{\mathrm{a}}$ & $2.5 \mathrm{~ns}$ & $18^{\mathrm{a}}$ & $2.7 \mathrm{~ns}$ \\
\hline \multicolumn{5}{|c|}{ Seedling Densities (pieces) } \\
\hline 150 & $17.3 \mathrm{~ns}$ & $2.8^{\mathrm{a}}$ & $19 \mathrm{~ns}$ & $2.7^{\mathrm{a}}$ \\
\hline 250 & $17.7 \mathrm{~ns}$ & $2.5^{\mathrm{b}}$ & $19 \mathrm{~ns}$ & $2.7^{\mathrm{a}}$ \\
\hline 350 & $17.3 \mathrm{~ns}$ & $2.3^{\mathrm{c}}$ & $16 \mathrm{~ns}$ & $2.4^{\mathrm{b}}$ \\
\hline 600 & $17.2 \mathrm{~ns}$ & $2.1^{\mathrm{d}}$ & $15 \mathrm{~ns}$ & $2.3^{\mathrm{c}}$ \\
\hline
\end{tabular}

*The values expressed in the same letters (a,b,c,d) indicate homogeneous groups; ns: insignificant
The highest average number of sub-branches (18) was counted in the treatment with $20 \mathrm{~g} / \mathrm{m}^{2}$ of nitrogen while the lowest average number of sub- branches $(15)$ was counted in the control. Therefore, by applying of $20 \mathrm{~g} / \mathrm{m}^{2}$ of $\mathrm{N}$, it is possible to increase the number of sub-branches approximately by $16 \%$. This positive effect is stronger with the increase of growing density (Figure 1).

For the shoot: root ratio, the highest average value (2.7) was measured at the growing density of 150-250 seedlings per square meter while the lowest average value (2.3) was measured at growing density of 600 seedlings per square meter. 


\section{Discussion and Conclusions}

As already known, the main purpose of nursery production is to plant as many seedlings as possible which are healthy, qualified and convenient to be able to be planted. In accordance with this purpose, firstly, the amount of seed to be sown per unit area should be determined according to tree species and habitat conditions. Since one of the most important factors effecting the quality of the seedlings to be used in reforestation efforts is the growing density. As a result of the studies carried out in different tree species, it is stated that as the growing density increases the root collar diameter decreases and the root collar diameter increases as the growing density decreases (Özdemir, 1971; Saatçioğlu, 1976; Şimşek, 1987; Mexal and Landis, 1990; South, 2000; Rose and Ketchum, 2003). Therefore, considering the economy of the business, especially in the arid and semi-arid areas where the root collar diameter is an important criterion of success, higher biological success will be achieved (Yahyaoğlu and Genç, 2000).

However, in addition to the growing density to be applied to the seedlings in their seedbeds, fertilization is one of the most important factors working on seedling quality. Because, the nutrient deficiencies in the soil, which are caused from consumption by millions of seedlings grown every year, may only be alleviated by appliying some amount of fertilizer. In this context, those seedlings grown with the adequate fertilizer are found to be more successful in the field (Tacenur and Efeoğlu, 1979; Öner et al., 2010; Oliet et al., 2011). As a result of this study, it is observed that fertilization is the most important factor effecting especially seedling height and number of sub branches. Similarly, in the conducted studies, it is stated that the seedling height is one of the best observation tool which shows the potential of afforestation, and the tall seedlings are more successful than the short ones in living covered and sloping and humid areas (Özdemir, 1971; Eyüboğlu, 1988).

Shoot:root ratio is the ratio of the dry weight of plant system above the collar root to the dry weight of the root system under the root collar (Ritchie, 1984; Ericsson, 1995; Jiménez et al., 2005; Haase, 2008). According to some research results, it is reported that the most effective criteria on the seedlings survival ratio on the land is the shoot:root ratio (Van den Driessche, 1991; Bernier et al., 1995; Tsakaldimi et al., 2012). As a result of this study, it was concluded that both growing density and fertilization have positive effects in terms of this character.

With all these reasons, the effects of growing density and fertilization were determined only on seedling morphological characteristics. Because, morphological characteristics are more preferable in classification of seedling quality in terms of ease of application of today (Mattsson, 1997; Semerci, 1997).

As a result of the assessment, the effect of growing density per unit on seedling height is statistically insignificant; however, the dose of applied fertilizer has proved to be more effective than growing density. In the meantime, when density levels and fertilizer doses were compared in terms of root collar diameter of seedlings, the observed differences in terms of quality emerged due to the growing density. In other words, the growing density effects root collar diameter more than the fertilization itself. The obtained results are similar to the previously conducted research results (Brissette et al., 1991; Simpson, 1991; South, 1993; Jinks and Mason, 1998; Williams and Stewart, 2006).

Based on the results of this study, we can recommend the growing density of $150-350$ seedlings per square meter for production of Crimean juniper seedlings targeted for afforestation in arid and semi-arid areas, where root collar diameter is an important attribute for success. Because, it was observed that when the number of seedlings decreased from 600 to 150 per square meter, a $32 \%$ of rise; a $19 \%$ increase when the number of seedlings were 250 , and a $10 \%$ raise when the number of seedlings were 350 .

Although the Crimean juniper is a tree species suitable for the extreme conditions in arid and semi-arid areas, application of at least $10 \mathrm{~g}$ nitrogen per square meter is recommended for the seedlings targeted to be planted at sites with dense competitive vegetation and adequate rain. Because, while the seedlings, to which $20 \mathrm{~g} \mathrm{~N}$ were given per square meter, grew longer $16 \%$ on average compared to those to which no fertilizers were given, those to which $10 \mathrm{~g}$ $\mathrm{N}$ were granted grew longer $11 \%$ on average. Therefore, increasing the fertilizer dose from 10 grams to 20 grams only results in an average increase of $5 \%$. Based on this reason, considering the economy of the business, it is thought that $10 \mathrm{~g} \mathrm{~N}$ per square meter will be more beneficial.

\section{References}

Bernier, P.Y., Lamhamedi, M.S., Simpson, D.G., 1995. Shoot:root ratio is of limited use in evaluating the quality of container conifer stock. Tree Planters' Notes, 46(3): 102-106.

Brissette, J.C., Barnett, J.P., Landis, T.D., 1991. Container seedlings. Forest regeneration manual, 36: 117-141.

Çiçek, E., Yilmaz, F., Yilmaz, M., 2010. Effect of N and NPK fertilizers on early field performance of narrow-leaved ash, Fraxinus angustifolia. Journal of Environmental Biology, 31(1): 109-114.

Ericsson, T., 1995. Growth and shoot:root ratio of seedlings in relation to nutrient availability. Plant and Soil, 62(168/169): 205-214.

Eyüboğlu, A. K., 1988. Fidanlıkta Değişik Sıklık Derecelerinde Yetiştirilmiş, Şaşırtılmış ve Şaşırtılmamış Doğu Ladini (Picea orientalis (L.) Link) Fidanlarının Arazideki Durumları. Forestry Research Institute, Ankara, Turkey.

Fisher, J.T., Mexal, G.J., 1984. Nutrition management: A physiological basis for yield improvement. Seedling Physiology and Reforestation Success, 14: 271-299.

Gezer, A., 1986. Doğu Karadeniz Göknarı (Abies nordmanniana Spach.)'nın Fidanlıklarda Yetiştirilme Tekniği Üzerine Araştırmalar. Poplar and Fast Growing Forest Trees Alien Species Research Institute. İzmit, Turkey.

Gond, D.P., Singh, S., Pal, A., Tewary, B.K., 2013. Growth, yield and metal residues in Solanum melongena grown in fly ash amended soils. Journal of Environmental Biology, 34(3): 539544.

Gültekin, H.C., Gülcü, S., Gültekin, U.G., Divrik, A., 2003. Boylu Ardıç (Juniperus excelsa Bieb) tohumlarına ekimden önce uygulanabilecek bazı basit sinıflandırma yöntemlerinin çimlenmeye olan etkilerinin belirlenmesi üzerine araştırmalar. Kafkas University, Artvin Faculty of Forestry Journal, 4(1): 111-121.

Haase, D.L., 2008. Understanding forest seedling quality: measurements and interpretation. Tree Planters' Notes, 52(2): 24-30. 
Jacobs, D.F., Salifu, K.F., Seifert, J.R., 2005. Relative contribution of initial root and shoot morphology in predicting field performance of hardwood seedlings. New Forests, 30(2-3): 235-251.

Jelin, J., Dhanarajan, M.S., Mariappan, V., 2013. Assessment of compost as a bio-fertilizer for the growth of paddy. Journal of Environmental Biology, 34(6): 975-979.

Jiménez, M.N., Navarro, F.B., Ripoll, M.Á., Bocio, I., De Simón, E., 2005. Effect of shelter tubes on establishment and growth of Juniperus thurifera L. (Cupressaceae) seedlings in Mediterranean semi-arid environment. Annals Forest Science, 62(7): 717-725.

Jinks, R., Mason, B., 1998. Effects of seedling density on the growth of Corsican pine (Pinus nigra var. maritime Melv.), Scots pine (Pinus sylvestris L.) and Douglas-fir (Pseudotsuga menziesii Franco) in containers. Annals Forest Science, 55(4): 407-423.

Kalıpsız, A., 1981. Statistical methods. Istanbul University, Faculty of Forestry Press., Istanbul, Turkey.

Larsen, H.S., South, D.B., Boyer, J.M., 1986. Root growth potential, seedling morphology and bud dormancy correlate with survival of loblolly pine seedlings planted in december in Alabama. Tree Physiology, 1(3): 253-263.

Long, A.J., Carrier, B.D., 1993. Effect of Douglas-fir 2+0 seedling morphology on field performance. New Forests, 7(1): 19-32.

Mattsson, A., 1997. Predicting field performance using seedling quality assessment. New Forests, 13(1-3): 227-252.

Mexal, J.G., Landis, T.D., 1990. Target seedling concepts: height and diameter. Target seedling symposium, meeting of the western forest nursery associations, General Technical Report RM-200, 1990: 17-35.

Negiz, M.G., Eser, Y., Kuzugüdenli, E., Özkan, K., 2015. Indicator species of essential forest tree species in the Burdur district. Journal of Environmental Biology, 36(1): 107-111.

Oliet, J.A., Salazar, J.M., Villar, R., Robredo, E., Valladares, F., 2011. Fall fertilization of Holm oak affects $\mathrm{N}$ and $\mathrm{P}$ dynamics, root growth potential, and post-planting phenology and growth. Annals of forest science, 68(3): 647-656.

Öner, N., Özden, S., Birben, U., 2010. Relationship between a natural monumental stand in Turkey and local beliefs. Journal of Environmental Biology, 31(1): 149-155.

Özdemir, Ö. L., 1971. Karaçam (Pinus nigra Arnold.) Fidanlıklarında Yetiştirilme Tekniği Üzerine Bazı Denemeler. Forestry Research Institute, Ankara, Turkey, 49: 51.

Puttonen, P., 1997. Looking for the "silver bullet', can one test do it all?. New Forests, 13(1-3): 9-27.

Ritchie, G.A., 1984. Assessing seedling quality. Forestry nursery manual: production of bareroot seedlings, 11: 243-259.

Rose, R., Ketchum, J.S., 2003. Interaction of initial seedling diameter, fertilization, and weed control on Douglas-fir growth over the first four years after planting. Annals of Forest Science, 60(7): 625-635.
Saatçioğlu, F., 1976. Silvikültürün Biyolojik Esasları ve Prensipleri. Istanbul University, Faculty of Forestry press., Istanbul, Turkey.

Semerci, A., 1997. Orman ağacı fidanlarında kök büyüme potansiyelinin (kbp) belirlenmesi. Journal of Central Anatolia Forestry Research Institute, 81: 15-40.

Sharma, V.K., Singh, R.P., 2011. Organic matrix based slow release fertilizer enhances plant growth, nitrate assimilation and seed yield of Indian mustard (Brassica juncea L.). Journal of Environmental Biology, 32(5): 619-624.

Simpson, D.G., 1991. Growing density and container volume affect nursery and field growth of interior spruce seedlings. Northern Journal of Applied Forestry, 8(4): 160-165.

South, D.B., 1993. Rationale for growing southern pine seedlings at low seedbed densities. New Forests, 7(1): 63-92.

South, D.B., 2000. Planting morphologically improved pine seedlings to increase survival and growth. Forestry and Wildlife Series, 1: 1-14.

Şimşek, Y., 1987. Ağaçlandırmalarda Kaliteli Fidan Kullanma Sorunlar1. Forestry Research Institute, 33(1): 5-29.

Tacenur, İ. A., Efeoğlu, A. İ., 1979. Türkiye' nin Bazı Orman Fidanlıklarında Üretilen İğne Yapraklı Fidanların Aldığı Besin Maddeleri ve Gübreleme Gereksinimi Üzerine Araştırmalar. TUBITAK Press., Ankara, Turkey.

Tetik, M., 1995. Sarıkamış fidanlığında ekim sıklığının Sarıçam (Pinus silvestris L.) fidanların kalitesine ve dikimdeki başarısına etkileri. Forestry Research Institute, Ankara, Turkey.

Tsakaldimi, M., Ganatsas, P., Jacobs, D.F., 2012. Prediction of planted seedling survival of five Mediterranean species based on initial seedling morphology. New Forests, 44(3): 327-339.

Trubat, R., Cortina, J., Vilagrosa, A., 2010. Nursery fertilization affects seedling traits but not field performance in Quercus suber L. Journal of arid environments, 74(4): 491-497.

Ürgenç, S., 1986. Afforestation technique. Istanbul University, Faculty of Forestry press., Istanbul, Turkey.

Van den Driessche, R., 1991. Influence of container nursery regimes on drought resistance of seedlings following planting: survival and growth. Canadian Journal of Forest Research, 21(5): 555-565

Williams, H.M., Stewart, T., 2006. The effects of sower and bed density on bareroot loblolly pine seedling morphology and early height growth. General Technical Report SRS-92, U.S Department of Agriculture, Forest Service, Southern Research Station, 2006: 45-49.

Yahyaoğlu, Z., Genç, M., 2000. Fidan Standardizasyonu (Kaliteli Fidan Yetistirme ve Fidan Kalite Sinıflandırması Esasları) Ders Kitabı. Kafkas University, Faculty of Forestry Press., Artvin, Turkey.

Yildiz, N., Bircan, H., 1991. Research and experimental methods. Atatürk University Press., Erzurum, Turkey.

Yildiz, N., Bircan, H., 1994. Applied statistics. Atatürk University Press., Erzurum, Turkey. 